OPEN ACCESS

Edited by:

Philippe De Deurwaerdere, Université de Bordeaux, France

Reviewed by: Karim Fifel, Université Claude Bernard Lyon 1, France Micaela Morelli, University of Cagliari, Italy

${ }^{*}$ Correspondence: Gillberto Fisone gilberto.fisone@ki.se

Specialty section: This article was submitted to

Neuropharmacology, a section of the journal

Frontiers in Pharmacology

Received: 09 September 2019 Accepted: 07 November 2019 Published: 27 November 2019

Citation: Medeiros DdC, Lopes Aguiar C, Moraes MFD and Fisone $G$ (2019) Sleep Disorders in Rodent Models of Parkinson's Disease.

Front. Pharmacol. 10:1414. doi: 10.3389/fphar.2019.01414

\section{Sleep Disorders in Rodent Models of Parkinson's Disease}

\author{
Daniel de Castro Medeiros ${ }^{1,2}$, Cleiton Lopes Aguiar ${ }^{2}$, Márcio Flávio Dutra Moraes² \\ and Gilberto Fisone ${ }^{1 *}$ \\ ${ }^{1}$ Department of Neuroscience, Karolinska Institutet, Stockholm, Sweden, ${ }^{2}$ Núcleo de Neurociências, Departamento de \\ Fisiologia e Biofísica, Instituto de Ciências Biológicas, Universidade Federal de Minas Gerais, Belo Horizonte, Brazil
}

Sleep disorders are frequently diagnosed in Parkinson's disease and manifested in the prodromal and advanced stages of the disease. These conditions, which in some cases affect more than 50\% of Parkinson's disease (PD) patients, include hypersomnia, often manifested as excessive daytime sleepiness, insomnia, characterized by delayed initiation and fragmentation of sleep at night, and disruption of rapid eye movement (REM) sleep, resulting in loss of atonia and dream enactment. Standard dopamine replacement therapies for the treatment of motor symptoms are generally inadequate to combat sleep abnormalities, which seriously affect the quality of life of PD patients. Rodent models still represent a major tool for the study of many aspects of PD. They have been primarily designed to eliminate midbrain dopamine neurons and elicit motor impairment, which are the traditional pathological features of PD. However, rodent models are increasingly employed to investigate non-motor symptoms, which are often caused by degenerative processes affecting multiple monoaminergic and peptidergic structures. This review describes how neurotoxic and genetic manipulations of rats and mice have been utilized to reproduce some of the major sleep disturbances associated with PD and to what extent these abnormalities can be linked to nondopaminergic dysfunction, affecting for instance noradrenaline, serotonin, and orexin transmission. Strengths and limitations are discussed, as well as the consistency of results obtained so far, and the need for models that better reproduce the multisystemic neurodegenerative nature of PD, thereby allowing to replicate the complex etiology of sleep-related disorders.

Keywords: sleep, rapid eye movement sleep, slow wave sleep, rat, mouse, disease models, 6-hydroxydopamine, 1-methyl-4-phenyl-1,2,3,6-tetrahydropyridine

\section{INTRODUCTION}

Since their first description two centuries ago, the symptoms of Parkinson's disease (PD) have been regularly re-assessed to include a large number of nonmotor conditions affecting both the peripheral and the central nervous system (Chaudhuri and Odin, 2010; Lang, 2011). This has occurred in parallel with the recognition of the complexity of the neurodegenerative processes at the basis of $\mathrm{PD}$, whose 
definition extends beyond that of a simple dopaminergic disorder Indeed, accurate analyses of the spread of $\alpha$-synuclein pathology from the peripheral nervous system, lower brainstem, and olfactory bulb, to the diencephalon, basal forebrain, and neocortex, show that $\mathrm{PD}$ affects not only dopamine, but also noradrenaline, serotonin, and acetylcholine containing structures (Braak et al., 2003).

This diversified pathology has been correlated to the gradual appearance of non-motor symptoms. For instance, gastrointestinal, bladder, and olfactory dysfunctions, which are common preclinical features of PD, have been linked to the initial stage of the disease, affecting the autonomic nervous system and olfactory nuclei. Other conditions, including sleep disturbances and affective disorders appear in conjunction with the caudal-rostral spread of a-synuclein deposition to the locus ceruleus, raphe, and lateral tegmental nuclei. Additional non-motor symptoms include cognitive dysfunction, often developing into dementia during the late stages of PD (Chaudhuri and Odin, 2010; Lang, 2011).

Sleep disorders are among the most frequent symptoms observed in PD patients, with a prevalence of $60-70 \%$ (De Cock et al., 2008; Barone et al., 2009; Neikrug et al., 2013). They often appear in the early stages of the disease and are considered as markers of prodromal parkinsonism (Schenck et al., 1996; Postuma et al., 2010; Lysen et al., 2019). Sleep-related symptoms in PD consist of a broad spectrum of conditions, which include hypersomnia, the difficulty in initiating and maintaining sleep and disturbances of rapid eye movement (REM) sleep. These disorders progressively worsen in the course of PD and represent a major factor affecting the patient's quality of life (Maetzler et al., 2009; Neikrug et al., 2013). They are generally refractory to, or exacerbated, by standard antiparkinsonian medications. In this context, it should be mentioned that impaired synaptic downscaling associated with sleep disruption may promote the emergence of motor complications caused by standard pharmacological therapy (Galati et al., 2015), and that this idea is supported by clinical studies indicating a correlation between disrupted sleep and 1-3,4-dihydroxyphenylalanine (L-DOPA)induced dyskinesia (Mao et al., 2018).

Several studies show that surgical treatment, specifically deep brain stimulation targeting the subthalamic nucleus, ameliorates sleep quality in PD (Arnulf et al., 2000; Antonini et al., 2004; Cicolin et al., 2004; Hjort et al., 2004; Kharkar et al., 2018). This could be explained by the ability of this intervention to counteract motor disturbances (Arnulf et al., 2000), but additional effects possibly exerted on sleep structures cannot be excluded (Kharkar et al., 2018). In spite of these efforts, the progressive deterioration of sleep observed in a large proportion of patients still represents a major problem in the management of PD.

In this review, we describe and discuss current attempts to study PD-related sleep disorders in rodents, which represent the most common experimental animals used to model motor and non-motor symptoms of PD.

\section{Sleep Physiology}

Sleep is a natural and reversible state, defined by lack of mobility (or slight mobility) and relative unresponsiveness to internal and external stimuli (Carskadon and Dement, 2017), closely associated with the patient's general health condition and necessary for optimal cognitive functions (Scammell et al., 2017). In general, a typical sleep period encompasses recurrent cycle successions of two states with distinct physiological characteristics, as assessed by electroencephalography (EEG), and electromyography (EMG): non-REM (NREM) and REM sleep (Chokroverty, 2009). During NREM sleep, the EMG indicates a decrease of muscle activity and the EEG shows a predominance of slow oscillations $(0.5-4 \mathrm{~Hz})$. For this reason, NREM sleep is also referred to as slow-wave sleep (SWS). In contrast, the REM phase presents a desynchronized EEG pattern (similar to wakefulness) along with a drastic reduction of muscle tonus (Lee and Dan, 2012).

The sleep-wake brain states and muscle tonus are mainly regulated by the posterior hypothalamus and several nuclei in the brainstem, collectively named ascending activating (or arousal) system (AAS). This system projects to the thalamus, basal forebrain, neocortex, and to the spinal cord (Fuller et al., 2016) and is essential for arousal and wakefulness (Moruzzi and Magoun, 1949). The firing rate of the neural components in the AAS, which consist mainly of monoaminergic and cholinergic neurons, changes along NREM-REM sleep cycles (Jones, 2003). The sleep monoaminergic nuclei complex includes the noradrenergic locus coeruleus (LC) (Carter et al., 2010), the serotonergic dorsal and median raphe nuclei (Ito et al., 2013), the dopaminergic ventral periaqueductal gray matter (vPAG) (Lu et al., 2006), and the histaminergic tuberomammillary neurons (TMN) (Yu et al., 2014). These nuclei present high firing rates during the wake period, lower firing during NREM sleep and are almost silent throughout the REM state. Conversely, the cholinergic neurons, which are clustered in the pedunculopontine (PPT) and lateral dorsal tegmental nuclei, fire rapidly during wake and REM periods but slowly during NREM sleep (Boucetta et al., 2014).

The AAS receives inhibitory inputs from galanin and gamma-aminobutyric acid-ergic (GABAergic) neurons located in the ventrolateral preoptic area (VLPO) and median preoptic nucleus (Suntsova et al., 2007). These hypothalamic neurons present a faster firing rate during sleep and effectively shut down the AAS wake-promoting cells (Sherin et al., 1996; Lu et al., 2002). On the other hand, AAS afferents from the LC and dorsal raphe connect to VLPO neurons that are inhibited by norepinephrine and serotonin (Chou et al., 2002). This reciprocal inhibitory control acts as a feedback loop (neural flip-flop circuit), leading to the alternation and stability of sleep-wake competing states (Saper et al., 2001; Saper et al., 2005). In addition, the AAS includes afferent connections from GABAergic neurons in the substantia nigra pars reticulata and from orexins (orexin-A and orexin-B; also known as hypocretin-1 and 2) containing neurons in the lateral hypothalamus (LH) (de Lecea et al., 1998; Sakurai et al., 1998). While the former induces NREM-REM states via inhibition of dorsal raphe and LC (Liu and Dan, 2019), the later promotes wake and suppresses sleep (particularly REM sleep) (Scammell et al., 2017) by activating LC and TMN (Peyron et al., 1998). 
REM sleep is also controlled by means of a mutual inhibition between neuronal circuits located in the mesopontine tegmentum. The sub-laterodorsal nucleus and precoeruleus region comprise the REM-promoting (REM-on) structures. Glutamatergic neurons projecting from these regions regulate the activity of the basal forebrain and medulla, thereby promoting cortical high-frequency paradoxical oscillations and muscle atonia typical of REM sleep. The REM-off nuclei, i.e., vPAG and lateral pontine tegmentum, provide a REM flipflop switch arrangement via GABAergic inhibition of REM-on nuclei (Peever and Fuller, 2017).

Hypothalamic and brainstem neurotransmitter systems modulate the REM-switch structures and support the sleep cycles. LC noradrenergic and dorsal raphe serotonergic neurons suppress REM sleep by exciting REM-off and inhibiting REM-on areas, whereas lateral dorsal tegmental and PPT cholinergic neurons promote REM by opposite actions on the same REM-on/ off populations. Additionally, orexin neurons excite REM-off structures and support sleep-wake stabilization, whereas the VLPO promotes the entry into REM sleep by inhibiting the same targets (Lu et al., 2006; Peever and Fuller, 2017).

Transitions between sleep and wake are thought to be regulated by two main processes-the homeostatic process (process S) and the circadian pacemaker (process C) (Borbély et al., 2016). Prolonged periods of wakefulness are followed by a corrective higher amount of sleep, referred to as sleep rebound. This homeostatic response is mediated by substances (somnogens) that accumulate during the wake periods and dissipate during sleep. One of the best-known somnogens is adenosine, a paracrine mediator produced by the degradation of ATP (Porkka-Heiskanen et al., 1997). Higher extracellular levels of adenosine promote sleep-state by inhibiting the AAS via adenosine A1 receptor (Strecker et al., 2000) and stimulating VLPO via A2 receptors (Scammell et al., 2001). The circadian pacemaker opposes the homeostatic process during the active period of the sleep-wake cycle, via the suprachiasmatic nucleus, which promotes wakefulness via excitation of LH orexin neurons and inhibition of VLPO neurons (Saper et al., 2005).

\section{Sleep Disturbances in Parkinson's Disease}

The progression of $\mathrm{PD}$ affects multiple neurotransmitter pathways that extend beyond dopaminergic degeneration in the substantia nigra pars compacta (SNc) (Braak et al., 2004; Surmeier et al., 2017), often comprising structures related to the sleep-wake cycle (French and Muthusamy, 2016). In fact, most PD patients present neuronal cell loss and Lewy bodies in the noradrenergic neurons of the locus coeruleus (Zarow et al., 2003), serotonergic and dopaminergic neurons in medial and dorsal raphe and vPAG (Halliday et al., 1990), as well as cholinergic, histaminergic, and orexinergic neurons in the pedunculopontine nuclei (PPN), TMN, and LH (Zweig et al., 1989; Fronczek et al., 2008; Shan et al., 2012; French and Muthusamy, 2018). Disruptions of these structures and connected circuits are likely to play an important role in sleep disturbances, such as insomnia, excessive daytime sleepiness (EDS), and REM sleep behavior disorder (RBD). In addition to these conditions, sleep in PD is influenced by motor abnormalities, such as restless legs syndrome, which can seriously compromise nocturnal sleep, and breathing disorders, leading to sleep apnea (Mery et al., 2017; FeriniStrambi et al., 2018). Altogether, these disturbances seriously contribute to fragmented sleep-wake behavior observed in PD.

Insomnia is one of the most common sleep disorders in $\mathrm{PD}$, affecting up to $60 \%$ of patients (Gjerstad et al., 2007). It is defined by a repeated difficulty in sleep initiation, duration, consolidation, or quality that occurs despite adequate time or opportunity for sleep (Thorpy, 2009). PD-related insomnia presents a multifactorial etiology and is often manifested as comorbidity rather than a single sleep problem (Ylikoski et al., 2015). The role played in PD-related insomnia by lesions affecting brain structures directly involved in arousal and sleep-wake behavior should not be overlooked. However, a number of motor conditions intrinsic to the disease process or induced by dopamine replacement therapy, such as tremor, restless legs syndrome, nighttime cramps, dystonia, and dyskinesia, play an essential role in the pathophysiology of PD-related insomnia (Arnulf et al., 2000). Similarly, nonmotor symptoms including autonomic dysfunction and psychiatric symptoms have also been associated with both insomnia and hypersomnia (Kurtis et al., 2013). Drug-disease interaction is also associated with insomnia in PD patients. For example, D1 and D2 receptors activation by higher doses of dopaminergic medication at bedtime are correlated with poor sleep quality (Chahine et al., 2013).

EDS is diagnosed in $15-50 \%$ of PD patients (Ondo et al., 2001) and is characterized by a disabling urge to nod or fall asleep during different daily-life circumstances, with a severe negative impact on the overall quality of life (Arnulf, 2005). The damage in the AAS nuclei is an essential factor in PD related EDS (Arnulf and Leu-Semenescu, 2009), particularly the degeneration of hypothalamic orexin cells (Fronczek et al., 2008), whose activity is crucial for vigilance maintenance (Sakurai, 2007; Ono and Yamanaka, 2017) and for the suppression of pathological intrusions of REM sleeprelated events during wakefulness (narcolepsy) (Hara et al., 2001). Additionally, EDS (somnolence) has direct correlation with the dosage of daytime dopamine agonist treatment (Avorn et al., 2005).

$\mathrm{RBD}$ is defined by the loss of normal REM atonia with prominent out-of-dreams muscle activation (Schenck et al., 2002), which may result in severe injuries to patients and their family. RBD affects approximately $30 \%$ of patients with PD (Barone et al., 2009) and is associated with loss of volume and neuronal degeneration in brainstem REM-on areas (Boeve et al., 2007; Garcia-Lorenzo et al., 2013; Boucetta et al., 2016), which may be caused by the pathological accumulation of $\alpha$-synuclein (Braak et al., 2004). Additionally, REM-sleep stability may be compromised by multiple degeneration of serotonergic, noradrenergic, cholinergic, and orexinergic nuclei that support and modulate the REM-switching system (Boeve et al., 2007; Fronczek et al., 2007; Garcia-Lorenzo et al., 2013; Boucetta et al., 2016; French and Muthusamy, 2018). 


\section{Rodent Models of Parkinson's Disease for the Study of Non-Motor Symptoms}

The multiple neurodegenerative processes potentially involved in non-motor symptoms contrast with the relatively wellestablished cause at the basis of the cardinal motor symptoms of $\mathrm{PD}$, i.e., the progressive degeneration of dopamine neurons in the SNc, projecting to the dorsal striatum (DS). Because of the traditional view of $\mathrm{PD}$ as a motor disorder, the development of experimental models has been centered on the elimination of the dopamine nigrostriatal pathway. This is generally achieved by local or systemic administration of neurotoxins (Tieu, 2011) or by genetic manipulations (Dawson et al., 2010).

\section{Neurotoxin Models of Parkinson's Disease}

Neurotoxin models of PD are commonly based on the use of 6-hydroxydopamine (6-OHDA) (Simola et al., 2007) or 1-methyl-4-phenyl-1,2,3,6-tetrahydropyridine

(MPTP) (Meredith and Rademacher, 2011). These compounds act by inhibiting mitochondrial function and generating reactive oxygen species, ultimately leading to oxidative stress and cell death (Simola et al., 2007; Meredith and Rademacher, 2011). In the mouse, repeated systemic administration of MPTP leads to a substantial loss of dopamine neurons and fibers. Depending on dose and regimen, MPTP has been reported to produce from 20 to $70 \%$ neuronal loss in the SNc and from 50 to $90 \%$ decrease in dopamine levels in the DS (Jackson-Lewis and Przedborski, 2007; Meredith and Rademacher, 2011).

6-OHDA is typically administered via stereotaxic injection in the medial forebrain bundle (MFB), dopaminergic midbrain nuclei (e.g., SNc) or directly into the DS of rats and mice. The injection in the MFB produces a nearly complete loss of nigrostriatal dopamine, mimicking end-stage PD (Yuan et al., 2005). This approach is normally utilized in combination with a unilateral lesion since a total bilateral elimination of dopamine would result in high mortality. Bilateral lesions are most frequently performed by injecting 6-OHDA in the DS, which leads to a partial loss of dopamine neurons in the $\mathrm{SNc}$ and a reduction of striatal dopamine varying between 45 and 75\% (Tadaiesky et al., 2008; Branchi et al., 2010; Bonito-Oliva et al., 2013). This latter approach is regarded as a model of early stage PD (Yuan et al., 2005).

Because of its similarity to endogenous catecholamines, 6-OHDA produces a combined degeneration of dopamine and noradrenaline neurons. This has been described in initial studies in rats (Breese and Traylor, 1971) and observed also in the mouse model of partial striatal lesion (Bonito-Oliva et al., 2014). In addition, both 6-OHDA and MPTP have been shown to decrease serotonin levels in the hippocampus (Reader and Gauthier, 1984; Santiago et al., 2010). The ability of these toxins to affect multiple neurotransmitter systems altered in $\mathrm{PD}$, is especially important for the study of non-motor symptoms.

\section{Sleep Disturbances in the 6-Hydroxydopamine Model of Parkinson's Disease}

Rats with a unilateral 6-OHDA lesion of the MFB show decreased sleep time during the light-on, inactive phase of the 24-h light-dark cycle, and increased total wake time assessed during a 24-h recording (Vo et al., 2014). When compared to naïve animals, these animals also show increased muscle activity during REM sleep, which is indicative of RBD-like abnormalities (Vo et al., 2014). Sleep analysis has recently been performed in rats injected unilaterally with 6-OHDA in the $\mathrm{SNc}$, which results in a substantial loss of dopamine neurons (Ciric et al., 2019). This intervention leads to increased number and mean duration of wake episodes assessed by cortical and hippocampal EEG during $6 \mathrm{~h}$ within the inactive, light-on period (Ciric et al., 2019). Increased wake time, particularly evident during the 12-h dark period, has also been observed in rats with a selective 6-OHDA lesion of the SNc (Qiu et al., 2016). Conversely, cortical EEG recording in rats injected with 6-OHDA in the lateral ventricle showed decreased wakefulness and augmented SWS (Monti et al., 1999). This difference is likely explained by the more generalized effect on multiple components of the catecholamine system exerted by intracerebroventricular (i.c.v.) administration of 6-OHDA, in comparison to selective stereotactic injections in MFB or SNc (Vo et al., 2014; Ciric et al., 2019).

Sakata et al. investigated the effect of bilateral 6-OHDA lesion of the ventral tegmental area (VTA) on sleep-wake cycles (Sakata et al., 2002). They found reduced REM sleep during the light-on period, in comparison with control rats. The 6-OHDA-lesion rats also displayed reduced wake duration and spontaneous activity accompanied by a significant increase of both REM and SWS (NREM) during the dark phase (Sakata et al., 2002). These findings are in line with some of the disturbances observed in PD patients, who are affected by insomnia at night and daytime sleepiness.

Further studies in rats showed that injection of 6-OHDA in the DS or MFB decreases the number of orexin neurons in the LH (Cui et al., 2010; Oliveira et al., 2018), thereby reproducing a similar damage described in PD (Maeda et al., 2006; Thannickal et al., 2007). This loss was paralleled by reduced baseline respiratory frequency during sleep in the light-on period (Oliveira et al., 2018), a condition reminiscent of breathing disturbances and sleep apnea observed in PD patients (Mery et al., 2017; Videnovic, 2017). The same 6-OHDA lesion did not affect the sleep-wake cycle (Oliveira et al., 2018). This contrasts with previous work in which LH orexinergic neurons were preferentially targeted using a neurotoxin acting through the ribosome-inactivating protein saporin (hypocretin2-saporin) (Gerashchenko et al., 2001). In this case, the authors found increased NREM and REM sleep during the dark, active phase, and sleep fragmentation leading to reduced number of REM sleep episodes during the light-on phase (Gerashchenko et al., 2001). Similar changes of REM and NREM sleep in the light-off period, were observed using a cycad toxin-based PD model (see below), which leads to a significant reduction in orexin neurons $(\mathrm{McD}$ owell et al., 2010). It should be noted however that in the 6-OHDA study EEG recordings were performed during the last $3 \mathrm{~h}$ of the light period and the first $3 \mathrm{~h}$ of the dark period (Oliveira et al., 2018), instead of the more appropriate 24 -h continuous recordings, as 
in the previous studies using saporin or cycad (Gerashchenko et al., 2001; McDowell et al., 2010).

Urethane anesthesia is characterized by alternations of oscillatory states which resemble REM-NREM cycling during natural sleep. Despite the obvious limitation of this approach, a number of studies have performed electrophysiological recordings in rodents under urethane to test mechanistic and functional hypothesis related to sleep-like states (Clement et al., 2008; Gonzalez-Rueda et al., 2018; Hauer et al., 2019). Resting-state functional magnetic resonance has been recently employed to examine modifications of functional connectivity in urethaneanesthetized rats with a unilateral partial striatal 6-OHDA-lesion (Zhurakovskaya et al., 2019). In this study, REM- and NREMlike sleep states were identified based on their association with high and low breathing rates, respectively (Pagliardini et al., 2012; Zhurakovskaya et al., 2019). Rats with a 6-OHDA lesion showed diminished intra-cortical, cortico-hippocampal, and striato-cortical functional connectivity, in comparison to naïe, or sham-lesion rats. Notably, these abnormalities were observed only during REM-like sleep (i.e., during states associated with high breathing rate), and may point toward changes in muscle tone suggestive of RBD (Zhurakovskaya et al., 2019). However, it remains to be established whether these alterations of connectivity can also be observed during sleep.

\section{Sleep Disturbances in the 1-Methyl-4-Phenyl-1,2,3,6- Tetrahydropyridine Model of Parkinson's Disease}

Sleep disruptions have also been observed in the MPTP model of PD. However, these alterations are transitory, which could be ascribed to limited or reversible neuronal loss, as well as to parallel compensatory effects (Johannessen et al., 1985; Saitoh et al., 1987; Bezard et al., 2000). Mice treated with five daily injections of MPTP $(25 \mathrm{mg} / \mathrm{kg})$ showed increased REM sleep during the 24-h light/dark cycle, in comparison to control. However, this effect was observed only 20 days after toxin injection and disappeared 40 days post MPTP (Monaca et al., 2004; Laloux et al., 2008). Interestingly, the reduction of dopamine neurons produced by MPTP, which was restricted to the SNc and amounted to approximately 30\%, remained constant for up to 60 days, suggesting the existence of mechanisms correcting for the neuronal loss produced by the toxin (Laloux et al., 2008). In contrast to the aforementioned work, EEG analysis performed in mice 14 days after a single injection of MPTP $(40 \mathrm{mg} / \mathrm{kg})$, reported increased wake, and decreased NREM sleep during the light-off period, but no change in REM sleep. In this study, however, MPTP produced a large reduction of dopamine neurons in both SNc (78\%) and VTA (54\%) (Revishchin et al., 2016).

A study in the rat, examined the effect on sleep patterns of local injection of MPTP in the SNc, leading to a temporary $(24 \mathrm{~h}) 50 \%$ decrease of tyrosine hydroxylase (a marker of dopamine neurons) (Lima et al., 2007). The authors observed a decrease in the latency to SWS onset during both the light-on and light-off periods, which lasted for up to 5 days following MPTP administration. This change was accompanied by increased sleep efficiency and may represent a surrogate marker of daytime sleepiness in PD. The same study also reported a significant increase in the latency to REM sleep in the MPTP rats compared to control animals. However, this disturbance was transient and disappeared 3 days after the administration of MPTP (Lima et al., 2007).

\section{Sleep Disturbances in Other Toxin-Based Models of Parkinson's Disease}

Chronic administration of rotenone, a natural compound commonly used as a pesticide, leads to a significant degeneration of $\mathrm{SNc}$ dopamine neurons accompanied by a-synuclein inclusions (Betarbet et al., 2000; Alam and Schmidt, 2002). Working with a rotenone-based rat model of $\mathrm{PD}$, Yi et al. reported increased SWS and REM sleep during the light-off active period and decreased SWS during the light-on period (Yi et al., 2007). These modifications, which are suggestive of PD-related daytime sleepiness and nighttime insomnia, were largely refractory to L-DOPA. Notably, the effect of rotenone was accompanied by increased hypothalamic levels of interleukin- $1 \beta$, a cytokine previously shown to promote REM and NREM sleep (Krueger, 2008). In line with this observation, i.c.v. administration of the endogenous interleukin-1 receptor antagonist (IL-1RA) counteracted the changes in SWS produced by rotenone during both the active and inactive 12-h periods (Yi et al., 2007). A word of caution should be spent concerning the solution (1:1 DMSO/PEG) commonly used to dissolve rotenone. In one study, this vehicle precluded a conclusive interpretation of the results, since it produced sleep anomalies that occluded those possibly caused by the neurotoxin (GarciaGarcia et al., 2005); but see (Yi et al., 2007). For this reason, particular care should be taken to include appropriate controls when employing the rotenone model.

In the rat, consumption of seeds from the plant Cycas micronesica (cycad) results in degeneration and accumulation of a-synuclein aggregates in dopaminergic and noradrenergic neurons of the SNc and LC (Shen et al., 2010). Sleep analysis performed in this model reported increased NREM and REM sleep during the active 12-h phase. These changes were associated with increased average duration of NREM sleep and increased number of REM episodes (McDowell et al., 2010). Notably, the same study also reported a reduction in the number of orexin neurons in the LH of cycad-fed rats (McDowell et al., 2010), a change which is in line with previous work in orexin depleted rats (Gerashchenko et al., 2001) and may contribute to the observed sleep abnormalities.

Gerashchenko et al. utilized the hypocretin2-saporin neurotoxin (see Sleep Disturbances in the 6-Hydroxydopamine Model of Parkinson's Disease) (Gerashchenko et al., 2001) to lesion substantia nigra and VTA, thereby eliminating a large proportion of neurons (dopaminergic and non-dopaminergic) in both regions (Gerashchenko et al., 2006). In the substantia nigra, but not in the VTA, this intervention led to increased wakefulness and reduced amounts of NREM and REM sleep during light-on and light-off periods. These results are indicative of insomnia and are in part consistent with findings in rats with a selective dopamine lesion of SNc (see Sleep 
Disturbances in the 6-Hydroxydopamine Model of Parkinson's Disease and Sleep Disturbances in the 1-Methyl-4-Phenyl-1,2,3,6Tetrahydropyridine Model of Parkinson's Disease) (Lima et al., 2007; Ciric et al., 2019).

\section{Genetic Models of Parkinson's Disease}

Genetic models are commonly obtained by overexpressing genes linked to $\mathrm{PD}$, or mutations implicated in autosomaldominant or recessive forms of the disease. Additional approaches include interventions disrupting mitochondrial function or specific transcription factors (Dawson et al., 2010; Chesselet and Richter, 2011). These strategies allow the study of effects produced by molecular modifications implicated in familial forms of PD, and to reproduce the accumulation of a-synuclein, which is a hallmark of PD absent in 6-OHDAor acute MPTP-based models (Dawson et al., 2010; Tieu, 2011). The neuronal loss observed in genetic models of PD is generally less pronounced in comparison to that achieved with neurotoxins, particularly 6-OHDA (Dawson et al., 2010; Chesselet and Richter, 2011). However, this does not necessarily represent a limitation to their use, since PD related sleep disorders are often manifested during the early phase of the disease.

In the mouse, overexpression of human a-synuclein driven by the Thy-1 promoter (Thy1-aSyn) leads to a progressive disruption of the nigrostriatal pathway, resulting in a $40 \%$ decrease of striatal dopamine (Chesselet et al., 2012). McDowell et al. examined sleep structure in Thy1-aSyn mice and found reduced REM sleep during the 24-h sleep-wake cycle, accompanied by increased NREM sleep during the light-on, inactive period (McDowell et al., 2014). The same authors also observed increased activity during the light-off, wake phase (McDowell et al., 2014). However, analysis of circadian restactivity performed in Thyl-aSyn mice reported reduced wheelrunning particularly pronounced during dark (Kudo et al., 2011). This discrepancy may be accounted for by the different parameters employed to assess the active state of the animals, i.e., whole-body movements detected by telemetry (McDowell et al., 2014) vs. wheel-running (Kudo et al., 2011). Notably, both EEG (McDowell et al., 2014) and visual (Kudo et al., 2011) analysis of Thy1-aSyn mice revealed a delay in sleep onset, although during different phases of the 24-h light-dark period.

Circadian rhythm has been also examined in the MitoPark mouse model of PD, in which dopamine neurons are progressively eliminated by selective impairment of mitochondrial function (Ekstrand and Galter, 2009). MitoPark mice showed a general reduction of locomotor activity in concomitance with the gradual loss of dopamine neurons, accompanied by a severe disruption of circadian rhythm in constant darkness (Fifel and Cooper, 2014). A similar loss of endogenous rhythmicity has been observed in neurotoxin models of PD based on striatal (Masini et al., 2017) or ventricular (Gravotta et al., 2011) injection of 6-OHDA. Further studies will be necessary to understand the mechanisms at the basis of these abnormalities as well as their impact on sleep function and architecture.

Mice with reduced (95\%) levels of the vesicular monoamine transporter 2 (VMAT2) undergo nigrostriatal dysfunctions affecting the dopaminergic system, which replicate key pathologic features of PD (Caudle et al., 2007). This model displays a number of non-motor symptoms associated with PD, including anomalies of circadian and sleep function (Taylor et al., 2009). VMAT2-depleted mice show reduced ambulation during the active phase of the circadian period (Taylor et al., 2009). They also show a reduced latency to behavioral signs of sleep (Taylor et al., 2009), which contrasts with the delayed sleep onset observed in Thy1-aSyn mice (Kudo et al., 2011; McDowell et al., 2014). Notably, VMAT2-deficient mice show a concomitant reduction of dopamine, noradrenaline, and serotonin in striatum, hippocampus, and cortex (Taylor et al., 2009), which collectively may contribute to the wide range of non-motor symptoms observed in this model.

Altogether, the different findings reported in genetic models of PD fail to provide a coherent representation of one or more specific sleep alterations associated with PD. Aside from the contrasting effects on activity state observed in Thyl-aSyn mice, which may be attributable to different methodological approaches (see above), these inconsistencies are possibly a consequence of distinct genetic strategies (overexpression of a-synuclein as opposed to downregulation of VAMT2), which may produce unique alterations besides those affecting the dopaminergic system.

\section{CONCLUSIONS AND PERSPECTIVES}

Rodent models represent a simple and versatile tool to study not only the classic motor symptoms and complications (i.e., dyskinesia) of $\mathrm{PD}$, but also a number of non-motor co-morbidities. Nonetheless, the development of rat and mouse models of PD-related sleep disturbances has lagged behind in comparison, for instance, to affective and cognitive symptoms. The reason for this lies in part in the complexity of sleep-related disorders, both with regard to their behavioral manifestation and their relationship to distinct cellular and anatomical substrates. The difference in sleep architecture between rodents and humans represents an additional obstacle when interpreting results. In this regard, modeling PD in non-human primates constitutes a clear advantage, since in these animals, sleep structure and EEG patterns closely reproduce the consolidated, monophasic organization observed in humans (Hsieh et al., 2008), which contrasts with the more dispersed distribution of sleep states in rodents (Fifel et al., 2016).

A critical issue related to rat and mouse models, and more in general to all current animal models, is the difficulty to recapitulate the diversified nature of the degenerative processes at the basis of PD, thereby offering the possibility of examining the concomitant involvement of multiple neurotransmitter systems in sleep alterations. Thus, it is not surprising that rodent models of PD do not reproduce the full spectrum of sleep abnormalities associated with PD. However, in spite of these limitations some of these ailments have been reproduced in rats (Table 1). For instance, decreased SWS during the quiescent period, suggestive of insomnia, has been described after 6-OHDA-lesion of the MFB (Vo et al., 2014) and in the rotenone 
TABLE 1 | Sleep disturbances in neurotoxin and genetic rodent models of Parkinson's disease.

\begin{tabular}{|c|c|c|c|c|c|c|c|}
\hline Model & Procedure & Pathology & Wake & $\begin{array}{l}\text { NREM/SWS } \\
\text { sleep }\end{array}$ & REM sleep & Species & Reference \\
\hline 6-OHDA & $\begin{array}{l}\text { Injection }(200 \mu \mathrm{g} \text { in } \\
20 \mu \mathrm{l}) \text { in the lateral } \\
\text { ventricle }\end{array}$ & $\begin{array}{l}\text { Decreased DA } \\
\text { levels in DS }(\approx 40 \%) \\
\text { ventral striatum } \\
(\approx 50 \%)\end{array}$ & $\begin{array}{l}\text { Decreased in } \\
\text { light-on }\end{array}$ & $\begin{array}{l}\text { Increased in } \\
\text { light-on }\end{array}$ & Unaltered & Rat & Monti et al., 1999 \\
\hline 6-OHDA & $\begin{array}{l}\text { Bilateral injection } \\
\text { in VTA (with } \\
\text { desipramine) }\end{array}$ & $\begin{array}{l}\text { Decreased DA } \\
\text { neurons in VTA }\end{array}$ & $\begin{array}{l}\text { Decreased in } \\
\text { light-off }\end{array}$ & $\begin{array}{l}\text { Increased in } \\
\text { light-off }\end{array}$ & $\begin{array}{l}\text { Increased in light- } \\
\text { off and decreased } \\
\text { in light-on }\end{array}$ & Rat & Sakata et al., 2002 \\
\hline 6-OHDA & $\begin{array}{l}\text { Unilateral injection } \\
\text { in MFB (with } \\
\text { desipramine) }\end{array}$ & $\begin{array}{l}\text { Decreased DA } \\
\text { neurons in SNc } \\
\text { (unilateral, } \geq 95 \% \text { ) }\end{array}$ & $\begin{array}{l}\text { Increased total } \\
\text { time }(24 \mathrm{~h})\end{array}$ & $\begin{array}{l}\text { Decrease in } \\
\text { light-on }\end{array}$ & $\begin{array}{l}\text { Increased muscle } \\
\text { activity }\end{array}$ & Rat & Vo et al., 2014 \\
\hline 6-OHDA & $\begin{array}{l}\text { Bilateral injections } \\
(12 \mu \mathrm{g} / 0.5 \mu \mathrm{l}) \text { in DS }\end{array}$ & $\begin{array}{l}\text { Decreased }(\approx 70 \%) \\
\text { DA neurons in } \\
\text { SNc, reduced ( } 27 \\
\text { to } 39 \% \text { ) orexin } \\
\text { neurons in LH }\end{array}$ & Unaltered & $\begin{array}{l}\text { Unaltered duration } \\
\text { ( } \downarrow \text { breathing } \\
\text { frequency during } \\
\text { sleep) }\end{array}$ & $\begin{array}{l}\text { Unaltered duration } \\
\text { ( } \downarrow \text { breathing } \\
\text { frequency during } \\
\text { sleep) }\end{array}$ & Rat & $\begin{array}{l}\text { Oliveira et al., } \\
2018\end{array}$ \\
\hline 6-OHDA & $\begin{array}{l}\text { Partial unilateral } \\
\text { lesion of DS- } \\
\text { sleep states } \\
\text { identified by } \\
\text { breathing rat } \\
\text { fluctuations }\end{array}$ & $\begin{array}{l}\text { Decreased levels } \\
\text { of DA in the DS } \\
\text { (unilateral, } 51 \% \text { ) }\end{array}$ & $\mathrm{NI}$ & Duration unaltered & Duration unaltered & Rat & $\begin{array}{l}\text { Zhurakovskaya } \\
\text { et al., } 2019\end{array}$ \\
\hline 6-OHDA & $\begin{array}{l}\text { Unilateral injection } \\
\text { in SNc (12 or } 24 \\
\mu \mathrm{g})\end{array}$ & $\begin{array}{l}\text { Decreased DA } \\
\text { neurons (56 to } \\
>92 \% \text { ) along the } \\
\text { SNc rostro-caudal } \\
\text { axis (unilateral) }\end{array}$ & $\begin{array}{l}\text { Increased in } \\
\text { light-on ( } \uparrow \text { bout } \\
\text { number) }\end{array}$ & Unaltered & Unaltered & Rat & Ciric et al., 2019 \\
\hline MPTP & $\begin{array}{l}\text { Injection }(200 \mu g / 2 \\
\mu l) \text { in the SNc }\end{array}$ & $\begin{array}{l}\text { Transient ( } 24 \mathrm{~h}) \\
\text { decrease }(50 \%) \text { of } \\
\text { DA neurons in the } \\
\text { SNc (unilateral) }\end{array}$ & $\mathrm{NI}$ & $\begin{array}{l}\text { Decrease in } \\
\text { latency of light-on } \\
\text { and off (up to } 5 \\
\text { days after lesion) }\end{array}$ & $\begin{array}{l}\text { Transient ( } 2 \text { days) } \\
\text { increase of latency } \\
\text { in light-on and off }\end{array}$ & Rat & Lima et al., 2007 \\
\hline MPTP & $\begin{array}{l}\text { Five daily systemic } \\
\text { (i.p.) injections ( } 25 \\
\text { mg/kg)-test } 20 \\
\text { days after toxin } \\
\text { treatment }\end{array}$ & $\begin{array}{l}\text { Decreased DA } \\
\text { neurons in SNc } \\
(30 \%)\end{array}$ & $\begin{array}{l}\text { Unchanged ( } \downarrow \text { bout } \\
\text { number but } \uparrow \text { bout } \\
\text { length) }\end{array}$ & Unchanged & $\begin{array}{l}\text { Increased in } \\
\text { light-on and off } \\
\text { ( } \uparrow \text { bout length) }\end{array}$ & Mouse & $\begin{array}{l}\text { Monaca et al., } \\
2004\end{array}$ \\
\hline MPTP & $\begin{array}{l}\text { Five daily systemic } \\
\text { (i.p.) injections ( } 25 \\
\mathrm{mg} / \mathrm{kg} \text { )-test } 20 \\
\text { and } 40 \text { days after } \\
\text { toxin treatment }\end{array}$ & $\begin{array}{l}\text { Decreased DA } \\
\text { neurons in SNc } \\
(30 \%) \text { and terminals } \\
\text { in DS (50\%) up to } \\
60 \text { days after toxin } \\
\text { treatment }\end{array}$ & Unaltered & Unaltered & $\begin{array}{l}\text { Increased in dark } \\
\text { ( } \uparrow \text { bout number) at } \\
\text { day } 20 \text {, but not at } \\
\text { day } 40 \text {, after toxin } \\
\text { treatment }\end{array}$ & Mouse & Laloux et al., 2008 \\
\hline MPTP & $\begin{array}{l}\text { One systemic } \\
\text { (s.c.) injection ( } 40 \\
\mathrm{mg} / \mathrm{kg} \text { ) }\end{array}$ & $\begin{array}{l}\text { Decreased DA } \\
\text { neurons in SNc } \\
(78 \%) \text { and VTA } \\
(54 \%) \text { after } 17 \text { days }\end{array}$ & $\begin{array}{l}\text { Increased in light- } \\
\text { off at day } 14 \text { after } \\
\text { toxin treatment }\end{array}$ & $\begin{array}{l}\text { Decreased in light- } \\
\text { off at day } 14 \text { after } \\
\text { toxin treatment }\end{array}$ & No change & Mouse & $\begin{array}{l}\text { Revishchin et al., } \\
2016\end{array}$ \\
\hline Rotenone & $\begin{array}{l}\text { Infusion (s.c.) } 3 \\
\text { mg/kg/day for } 28 \\
\text { days }\end{array}$ & $\begin{array}{l}\text { Decrease }(\approx 70 \%) \text { of } \\
\text { DA neurons in SNc }\end{array}$ & $\begin{array}{l}\text { Decreased in dark } \\
\text { and increased in } \\
\text { light }\end{array}$ & $\begin{array}{l}\text { Increased in dark } \\
\text { ( } \uparrow \text { bout duration) } \\
\text { and decreased } \\
\text { in light ( } \downarrow \text { bout } \\
\text { number) }\end{array}$ & $\begin{array}{l}\text { Increased in dark } \\
\text { ( } \uparrow \text { bout number) }\end{array}$ & Rat & Yi et al., 2007 \\
\hline Cycad & $\begin{array}{l}\text { Feeding with pellet } \\
(1.25 \mathrm{~g}) \text { for } 22 \\
\text { weeks }\end{array}$ & $\begin{array}{l}\alpha \text {-syn aggregates } \\
\text { in DA neurons, } \\
\text { decreased DA } \\
\text { neurons in the SNc } \\
\text { and DA fibers in } \\
\text { DS, reduced orexin } \\
\text { neurons in the LH }\end{array}$ & $\begin{array}{l}\text { Decreased in light- } \\
\text { off (35\% } \uparrow \text { bout } \\
\text { number and } 50 \% \\
\downarrow \text { bout duration) }\end{array}$ & $\begin{array}{l}\text { Increased in light- } \\
\text { off ( } \uparrow \text { bout duration) }\end{array}$ & $\begin{array}{l}\text { Increased in light- } \\
\text { off ( } \uparrow \text { bout number) }\end{array}$ & Rat & $\begin{array}{l}\text { McDowell et al., } \\
2010\end{array}$ \\
\hline $\begin{array}{l}\text { Hypocretin2- } \\
\text { saporin }\end{array}$ & $\begin{array}{l}\text { Injection in SN and } \\
\text { VTA }\end{array}$ & $\begin{array}{l}\text { Non-selective } \\
\text { neuronal depletion } \\
\text { in both regions }\end{array}$ & $\begin{array}{l}\text { Increased during } \\
\text { light-on and off } \\
\text { (only in SN-lesion) }\end{array}$ & $\begin{array}{l}\text { Decreased during } \\
\text { light-on and off } \\
\text { (only in SN-lesion) }\end{array}$ & $\begin{array}{l}\text { Decreased during } \\
\text { light-on and off } \\
\text { (only in SN-lesion) }\end{array}$ & Rat & $\begin{array}{l}\text { Gerashchenko } \\
\text { et al. (2006) }\end{array}$ \\
\hline
\end{tabular}


TABLE 1 | Continued

\begin{tabular}{|c|c|c|c|c|c|c|c|}
\hline Model & Procedure & Pathology & Wake & $\begin{array}{l}\text { NREM/SWS } \\
\text { sleep }\end{array}$ & REM sleep & Species & Reference \\
\hline Thy-1 $\alpha$-Syn & Transgenic & $\begin{array}{l}\alpha \text {-syn aggregates } \\
\text { in SNc and } 40 \% \\
\text { reduction of striatal } \\
\text { DA at } 14 \text { months }\end{array}$ & $\begin{array}{l}\text { Increased active } \\
\text { wake in light-off }\end{array}$ & $\begin{array}{l}\text { Increased in light } \\
\text { ( bout length) - } \\
\uparrow \text { bout length in } \\
\text { dark }\end{array}$ & $\begin{array}{l}\text { Decreased in light- } \\
\text { off ( } \downarrow \text { bout number) } \\
\text { and light-on }\end{array}$ & Mouse & $\begin{array}{l}\text { McDowell et al., } \\
2014\end{array}$ \\
\hline $\begin{array}{l}\text { VMAT2- } \\
\text { deficiency }\end{array}$ & Transgenic & $\begin{array}{l}\text { Decreased DA, NE, } \\
\text { and 5-HT in DS, } \\
\text { hippocampus, and } \\
\text { cortex at 12-15 } \\
\text { months }\end{array}$ & $\begin{array}{l}\text { Decreased at } 4-6 \\
\text { months }\end{array}$ & Decreased sleep latency & & Mouse & Taylor et al., 2009 \\
\hline
\end{tabular}

NI, not investigated; i.p., intraperitoneal; s.c., subcutaneous; SN, substantia nigra; DA, dopamine; NE, noradrenaline; 5-HT, serotonin; $\alpha$-syn, $\alpha$-synuclein;

$\uparrow$, increased; $\downarrow$, decreased. See text for other abbreviations.

model (Yi et al., 2007). Moreover, 6-OHDA-lesion of the VTA (Sakata et al., 2002), as well as administration of rotenone (Yi et al., 2007), or cycad toxin (Shen et al., 2010) increase NREM and REM sleep during the active phase of the circadian cycle, which is indicative of EDS. These results are in line with the analysis of rest-wake circadian rhythm in mice with a bilateral striatal 6-OHDA-lesion, which show decreased activity during the active 12-h period (Masini et al., 2017).

Modifications in sleep architecture have also been observed in mice and rats intoxicated with MPTP (Monaca et al., 2004; Lima et al., 2007; Laloux et al., 2008; Revishchin et al., 2016) (Table 1). However, MPTP-based approaches have failed to provide consistent results and are often observed only during a limited period of time following administration of the toxin (Lima et al., 2007; Laloux et al., 2008). This limited efficacy is in line with the lack of alterations of circadian locomotor activity rhythm reported in mice following acute or chronic treatment with MPTP (Fifel et al., 2013).

How can rodent modeling of sleep disorders in PD be improved? Overall, a general effort should be made to refine and harmonize the different approaches used to generate neurotoxinbased models. In the case of 6-OHDA, for instance, rats have been treated with i.c.v. injection, unilateral and bilateral injections in $\mathrm{MFB}$, distinct midbrain dopaminergic nuclei (i.e., SNc and VTA), or in the striatum (see Table 1). Moreover, some studies (Sakata et al., 2002; Vo et al., 2014) have used pretreatment with desipramine, a selective inhibitor of noradrenaline reuptake. The different degree of dopamine and noradrenaline depletion produced by these interventions may cause distinct effects in sleep behavior, thereby contributing to discrepancies and confounding interpretations.

Combined loss of dopamine, noradrenaline, and to some extent functional inactivation of serotonin has been achieved with neurotoxins (Breese and Traylor, 1971; Reader and Gauthier, 1984; Santiago et al., 2010; Bonito-Oliva et al., 2013). In addition, 6-OHDA has been found to reduce the number of orexin/hypocretin neurons in the LH (Cui et al., 2010; Oliveira et al., 2018). Therefore, some of the sleep abnormalities observed in rodent models of PD may depend on the loss, or impairment, of one or more of these components of the arousal system. However, several key structures implicated in sleep regulation, including cholinergic and histaminergic nuclei, are spared by neurotoxin or genetic interventions. Therefore it will be important to strengthen construct validity of rodent models by establishing a more stringent link between the observed sleep abnormalities and PD-related biological dysfunctions.

The limitation posed by the relatively restricted neurodegenerative effects observed in most experimental models has been in part circumvented by acting on specific targets. For instance, bilateral injection of ibotenic acid in the PPN has been proposed to represent a model of PD cholinopathy (Ciric et al., 2018). In the rat, this intervention results in altered microstructure of both NREM and REM sleep during the inactive phase (Ciric et al., 2018). However, the neurotoxic effect exerted by ibotenic acid in the PPN is likely to affect not only cholinergic neurons, but also glutamatergic and GABAergic cells.

Chemo- and optogenetics techniques offer a particularly attractive approach to parse the involvement of neuronal networks in PD-related sleep-wake disturbances. For instance, using selective expression of designer receptor exclusively activated by designer drugs (DREADD) (Alexander et al., 2009), Kroeger et al. showed that distinct neuronal populations in the PPN regulate different aspects of sleep-wake behavior (Kroeger et al., 2017). Similar approaches, including optogenetic manipulation, showed that the dopamine neurons of the VTA are required for the initiation and maintenance of wakefulness (Eban-Rothschild et al., 2016; Oishi et al., 2017). Notably, these findings are in line with results obtained in rats with a selective 6-OHDA lesion of the VTA, which display decreased wakefulness during the active, light-off phase (Sakata et al., 2002).

Opto- and chemogenetic interrogation has also been employed to investigate the role in sleep of a population of dopamine neurons located in the dorsal raphe. These cells degenerate in PD (Halliday et al., 1990), but their involvement in non-motor symptoms remains to be in large part assessed. Cho et al. showed that ontogenetic stimulation of these dopamine population induces and maintains wakefulness and that vice versa their chemogenetic inhibition counteracts wakefulness and increases NREM sleep (Cho et al., 2017). In another study, Qiu et al. clarified the contribution to sleep of the external globus pallidus, whose activity is reduced in PD. It was found that, in the rat, activation of this structure resulted in enhanced sleep, possibly mediated via inhibition 
of cortical regions involved in the regulation of arousal nuclei (Qiu et al., 2016).

Recent evidence provides an attractive approach to reproduce the path of PD progression described by Braak et al. (2003). Injection of $a$-synuclein pathological fibrils in the gut muscle layer, leads to the spread of Lewy bodies from the peripheral nervous system, through the vagus nerve, to the brain, followed by loss of dopamine neurons (Kim et al., 2019). These effects are accompanied by motor impairment and by non-motor symptoms, including cognitive and affective deficits (Kim et al., 2019). The widespread distribution of $\alpha$-synuclein fibrils, which are observed in several structures including the LC, suggests the potential use in the future of this or similar models for the study of sleep-related co-morbidities in PD.

One particularly interesting aspect of sleep disorders in PD is their potential impact on other frequent non-motor symptoms, such as cognitive and affective disorders. Indeed, cycling and coordinated transition of NREM and REM sleep are implicated in learning and memory processes (Moroni et al., 2014; Boyce et al., 2016). The synchronous activation of hippocampal pyramidal neurons during sleep results in the propagation of information throughout the neocortex, thereby leading to memory consolidation (Buzsaki, 1989). Depression has also been correlated to reduced SWS and increased duration and intensity of REM sleep (Riemann et al., 2001). The existence of a causative

\section{REFERENCES}

Alam, M., and Schmidt, W. J. (2002). Rotenone destroys dopaminergic neurons and induces parkinsonian symptoms in rats. Behav. Brain Res. 136, 317-324. doi: 10.1016/S0166-4328(02)00180-8

Alexander, G. M., Rogan, S. C., Abbas, A. I., Armbruster, B. N., Pei, Y., Allen, J. A., et al. (2009). Remote control of neuronal activity in transgenic mice expressing evolved G protein-coupled receptors. Neuron 63, 27-39. doi: 10.1016/j.neuron.2009.06.014

Antonini, A., Landi, A., Mariani, C., DeNotaris, R., and Pezzoli, G. (2004). Deep brain stimulation and its effect on sleep in Parkinson's disease. Sleep Med. 5, 211-214. doi: 10.1016/j.sleep.2003.10.011

Arnulf, I., and Leu-Semenescu, S. (2009). Sleepiness in Parkinson's disease. Parkinsonism Relat. Disord. 15 Suppl 3, S101-S104. doi: 10.1016/ S1353-8020(09)70792-8

Arnulf, I., Bejjani, B. P., Garma, L., Bonnet, A. M., Houeto, J. L., Damier, P., et al. (2000). Improvement of sleep architecture in PD with subthalamic nucleus stimulation. Neurology 55, 1732-1734. doi: 10.1212/wnl.55.11.1732

Arnulf, I. (2005). Excessive daytime sleepiness in parkinsonism. Sleep Med. Rev. 9 , 185-200. doi: 10.1016/j.smrv.2005.01.001

Avorn, J., Schneeweiss, S., Sudarsky, L. R., Benner, J., Kiyota, Y., Levin, R., et al. (2005). Sudden uncontrollable somnolence and medication use in Parkinson disease. Arch. Neurol. 62, 1242-1248. doi: 10.1001/archneur.62.8.1242

Barone, P., Antonini, A., Colosimo, C., Marconi, R., Morgante, L., Avarello, T. P., et al. (2009). The PRIAMO study: a multicenter assessment of nonmotor symptoms and their impact on quality of life in Parkinson's disease. Mov. Disord. 24, 1641-1649. doi: 10.1002/mds.22643

Betarbet, R., Sherer, T. B., MacKenzie, G., Garcia-Osuna, M., Panov, A. V., and Greenamyre, J. T. (2000). Chronic systemic pesticide exposure reproduces features of Parkinson's disease. Nat. Neurosci. 3, 1301-1306. doi: 10.1038/81834

Bezard, E., Dovero, S., Imbert, C., Boraud, T., and Gross, C. E. (2000). Spontaneous long-term compensatory dopaminergic sprouting in MPTPtreated mice. Synapse 38, 363-368. doi: 10.1002/1098-2396(20001201)38: 3<363::AID-SYN16>3.0.CO;2-A

Boeve, B. F., Silber, M. H., Saper, C. B., Ferman, T. J., Dickson, D. W., Parisi, J. E., et al. (2007). Pathophysiology of REM sleep behaviour disorder and relevance link between PD-related sleep disruptions and psychiatric co-morbidities remain to be further investigated. In this regard, it should be mentioned that memory deficit, depression, and anxiety are commonly observed in rodent models of PD, which may therefore represent valuable tools to help clarifying some of these questions.

\section{AUTHOR CONTRIBUTIONS}

GF conceived the presented idea and supervised the project. DM and GF wrote the manuscript. CA and MM provided critical feedback and helped shape the manuscript. All authors approved the final version for submission.

\section{FUNDING}

This work was supported by the Swedish Research Council (grant 2015-02886), the Swedish Brain Foundation and the Swedish Parkinson Foundation (GF). This work is part of a joint Brazilian-Swedish Research Collaboration supported by the Swedish Foundation for International Cooperation in Research and Higher Education (STINT) and by the Coordenação de Aperfeiçoamento de Pessoal de Nível Superior (CAPES), Brazil.

to neurodegenerative disease. Brain 130, 2770-2788. doi: 10.1093/brain/ awm056

Bonito-Oliva, A., Pignatelli, M., Spigolon, G., Yoshitake, T., Seiler, S., Longo, F., et al. (2013). Cognitive impairment and dentate gyrus synaptic dysfunction in experimental parkinsonism. Biol. Psychiatry 75, 701-710. doi: 10.1016/j. biopsych.2013.02.015

Bonito-Oliva, A., Masini, D., and Fisone, G. (2014). A mouse model of non-motor symptoms in Parkinson's disease: focus on pharmacological interventions targeting affective dysfunctions. Front. Behav. Neurosci. 8, 290. doi: 10.3389/ fnbeh.2014.00290

Borbély, A. A., Daan, S., Wirz-Justice, A., and Deboer, T. (2016). The two-process model of sleep regulation: a reappraisal. J. Sleep Res. 25, 131-143. doi: 10.1111/jsr.12371

Boucetta, S., Cisse, Y., Mainville, L., Morales, M., and Jones, B. E. (2014). Discharge profiles across the sleep-waking cycle of identified cholinergic, GABAergic, and glutamatergic neurons in the pontomesencephalic tegmentum of the rat. J. Neurosci. 34, 4708-4727. doi: 10.1523/JNEUROSCI.2617-13.2014

Boucetta, S., Salimi, A., Dadar, M., Jones, B. E., Collins, D. L., and Dang-Vu, T. T. (2016). Structural brain alterations associated with rapid eye movement sleep behavior disorder in Parkinson's disease. Sci. Rep. 6, 26782. doi: 10.1038/srep26782

Boyce, R., Glasgow, S. D., Williams, S., and Adamantidis, A. (2016). Causal evidence for the role of REM sleep theta rhythm in contextual memory consolidation. Science 352, 812-816. doi: 10.1126/science.aad5252

Braak, H., Del Tredici, K., Rub, U., de Vos, R. A., Jansen Steur, E. N., and Braak, E. (2003). Staging of brain pathology related to sporadic Parkinson's disease. Neurobiol. Aging 24, 197-211. doi: S0197458002000659

Braak, H., Ghebremedhin, E., Rub, U., Bratzke, H., and Del Tredici, K. (2004). Stages in the development of Parkinson's disease-related pathology. Cell Tissue Res. 318, 121-134. doi: 10.1007/s00441-004-0956-9

Branchi, I., D’Andrea, I., Armida, M., Carnevale, D., Ajmone-Cat, M. A., Pezzola, A., et al. (2010). Striatal 6-OHDA lesion in mice: investigating early neurochemical changes underlying Parkinson's disease. Behav. Brain Res. 208, 137-143. doi: 10.1016/j.bbr.2009.11.020

Breese, G. R., and Traylor, T. D. (1971). Depletion of brain noradrenaline and dopamine by 6-hydroxydopamine. Br. J. Pharmacol. 42, 88-99. doi: 10.1111/ j.1476-5381.1971.tb07089.x 
Buzsaki, G. (1989). Two-stage model of memory trace formation: a role for "noisy" brain states. Neuroscience 31, 551-570. doi: 10.1016/0306-4522(89)90423-5

Carskadon, M. A., and Dement, W. C. (2017). Normal human sleep: an overview. Principles and practice of sleep medicine. 6th ed. 15-24.e13. doi: 10.1016/ b978-0-323-24288-2.00002-7

Carter, M. E., Yizhar, O., Chikahisa, S., Nguyen, H., Adamantidis, A., Nishino, S., et al. (2010). Tuning arousal with optogenetic modulation of locus coeruleus neurons. Nat. Neurosci. 13, 1526-1533. doi: 10.1038/nn.2682

Caudle, W. M., Richardson, J. R., Wang, M. Z., Taylor, T. N., Guillot, T. S., McCormack, A. L., et al. (2007). Reduced vesicular storage of dopamine causes progressive nigrostriatal neurodegeneration. J. Neurosci. 27, 8138-8148. doi: 10.1523/JNEUROSCI.0319-07.2007

Chahine, L. M., Daley, J., Horn, S., Duda, J. E., Colcher, A., Hurtig, H., et al. (2013). Association between dopaminergic medications and nocturnal sleep in early-stage Parkinson's disease. Parkinsonism Relat. Disord. 19, 859-863. doi: 10.1016/j.parkreldis.2013.05.009

Chaudhuri, K. R., and Odin, P. (2010). The challenge of non-motor symptoms in Parkinson's disease. Prog. Brain Res. 184, 325-341. doi: 10.1016/ S0079-6123(10)84017-8

Chesselet, M. F., and Richter, F. (2011). Modelling of Parkinson's disease in mice. Lancet Neurol. 10, 1108-1118. doi: 10.1016/S1474-4422(11)70227-7

Chesselet, M. F., Richter, F., Zhu, C., Magen, I., Watson, M. B., and Subramaniam, S. R. (2012). A progressive mouse model of Parkinson's disease: the Thy1-aSyn ("Line 61") mice. Neurotherapeutics 9, 297-314. doi: 10.1007/ s13311-012-0104-2

Cho, J. R., Treweek, J. B., Robinson, J. E., Xiao, C., Bremner, L. R., Greenbaum, A., et al. (2017). Dorsal raphe dopamine neurons modulate arousal and promote wakefulness by salient stimuli. Neuron 941205-1219, e1208. doi: 10.1016/j. neuron.2017.05.020

Chokroverty, S. (2009). An Overview of Normal Sleep. Sleep Disorders Medicine: Basic Science, Technical Considerations, and Clinical Aspects. 3rd edition 5-21. doi: 10.1016/b978-0-7506-7584-0.00002-1

Chou, T. C., Bjorkum, A. A., Gaus, S. E., Lu, J., Scammell, T. E., and Saper, C. B. (2002). Afferents to the ventrolateral preoptic nucleus. J. Neurosci. 22, 977-990. doi: 10.1523/JNEUROSCI.22-03-00977.2002

Cicolin, A., Lopiano, L., Zibetti, M., Torre, E., Tavella, A., Guastamacchia, G., et al. (2004). Effects of deep brain stimulation of the subthalamic nucleus on sleep architecture in parkinsonian patients. Sleep Med. 5, 207-210. doi: 10.1016/j. sleep.2003.10.010

Ciric, J., Lazic, K., Kapor, S., Perovic, M., Petrovic, J., Pesic, V., et al. (2018). Sleep disorder and altered locomotor activity as biomarkers of the Parkinson's disease cholinopathy in rat. Behav. Brain Res. 339, 79-92. doi: 10.1016/j. bbr.2017.11.021

Ciric, J., Kapor, S., Perovic, M., and Saponjic, J. (2019). Alterations of sleep and sleep oscillations in the Hemiparkinsonian Rat. Front. Neurosci. 13, 148. doi: 10.3389/fnins.2019.00148

Clement, E. A., Richard, A., Thwaites, M., Ailon, J., Peters, S., and Dickson, C. T. (2008). Cyclic and sleep-like spontaneous alternations of brain state under urethane anaesthesia. PloS One 3 (4), e2004. doi: 10.1371/journal. pone. 0002004

Cui, L. B., Li, B. W., Jin, X. H., Zhao, L., and Shi, J. (2010). Progressive changes of orexin system in a rat model of 6-hydroxydopamine-induced Parkinson's disease. Neurosci. Bull. 26, 381-387. doi: 10.1007/s12264-010-0410-9

Dawson, T. M., Ko, H. S., and Dawson, V. L. (2010). Genetic animal models of Parkinson's disease. Neuron 66, 646-661. doi: 10.1016/j.neuron.2010.04.034

De Cock, V. C., Vidailhet, M., and Arnulf, I. (2008). Sleep disturbances in patients with parkinsonism. Nat. Clin. Pract. Neurol. 4, 254-266. doi: 10.1038/ ncpneuro0775

de Lecea, L., Kilduff, T. S., Peyron, C., Gao, X. B., Foye, P. E., Danielson, P. E., et al. (1998). The hypocretins: hypothalamus-specific peptides with neuroexcitatory activity. Proc. Natl. Acad. Sci. 95, 322-327. doi: 10.1073/pnas.95.1.322

Eban-Rothschild, A., Rothschild, G., Giardino, W. J., Jones, J. R., and de Lecea, L. (2016). VTA dopaminergic neurons regulate ethologically relevant sleep-wake behaviors. Nat. Neurosci. 19, 1356-1366. doi: 10.1038/nn.4377

Ekstrand, M. I., and Galter, D. (2009). The mitopark mouse - an animal model of Parkinson's disease with impaired respiratory chain function in dopamine neurons. Parkinsonism Relat. Disord. 15 Suppl 3, S185-S188. doi: 10.1016/ S1353-8020(09)70811-9
Ferini-Strambi, L., Carli, G., Casoni, F., and Galbiati, A. (2018). Restless legs syndrome and Parkinson disease: a causal relationship between the two disorders? Front. Neurol. 9, 551. doi: 10.3389/fneur.2018.00551

Fifel, K., and Cooper, H. M. (2014). Loss of dopamine disrupts circadian rhythms in a mouse model of Parkinson's disease. Neurobiol. Dis. 71, 359-369. doi: 10.1016/j.nbd.2014.08.024

Fifel, K., Dkhissi-Benyahya, O., and Cooper, H. M. (2013). Lack of long-term changes in circadian, locomotor, and cognitive functions in acute and chronic MPTP (1-methyl-4-phenyl-1,2,3,6-tetrahydropyridine) mouse models of Parkinson's disease. Chronobiol. Int. 30, 741-755. doi: 10.3109/07420528.2012.762011

Fifel, K., Piggins, H., and Deboer, T. (2016). Modeling sleep alterations in Parkinson's disease: how close are we to valid translational animal models? Sleep Med. Rev. 25, 95-111. doi: 10.1016/j.smrv.2015.02.005

French, I. T., and Muthusamy, K. A. (2016). A review of sleep and its disorders in patients with Parkinson's disease in relation to various brain structures. Front. Aging Neurosci. 8, 114. doi: 10.3389/fnagi.2016.00114

French, I. T., and Muthusamy, K. A. (2018). A review of the Pedunculopontine nucleus in Parkinson's disease. Front. Aging Neurosci. 10, 99. doi: 10.3389/ fnagi.2018.00099

Fronczek, R., Overeem, S., Lee, S. Y., Hegeman, I. M., van Pelt, J., van Duinen, S. G., et al. (2007). Hypocretin (orexin) loss in Parkinson's disease. Brain 130, 15771585. doi: 10.1093/brain/awm090

Fronczek, R., Overeem, S., Lee, S. Y., Hegeman, I. M., van Pelt, J., van Duinen, S. G., et al. (2008). Hypocretin (orexin) loss and sleep disturbances in Parkinson's Disease. Brain 131, e88. doi: 10.1093/brain/awm222

Fuller, P. M., Gooley, J. J., and Saper, C. B. (2016). Neurobiology of the sleep-wake cycle: sleep architecture, circadian regulation, and regulatory feedback. J. Biol. Rhythms 21, 482-493. doi: 10.1177/0748730406294627

Galati, S., Salvade, A., Pace, M., Sarasso, S., Baracchi, F., Bassetti, C. L., et al. (2015). Evidence of an association between sleep and levodopa-induced dyskinesia in an animal model of Parkinson's disease. Neurobiol. Aging 36, 1577-1589. doi: 10.1016/j.neurobiolaging.2014.12.018

Garcia-Garcia, F., Ponce, S., Brown, R., Cussen, V., and Krueger, J. M. (2005). Sleep disturbances in the rotenone animal model of Parkinson disease. Brain Res. 1042, 160-168. doi: 10.1016/j.brainres.2005.02.036

Garcia-Lorenzo, D., Longo-Dos Santos, C., Ewenczyk, C., Leu-Semenescu, S., Gallea, C., Quattrocchi, G., et al. (2013). The coeruleus/subcoeruleus complex in rapid eye movement sleep behaviour disorders in Parkinson's disease. Brain 136, 2120-2129. doi: 10.1093/brain/awt152

Gerashchenko, D., Kohls, M. D., Greco, M., Waleh, N. S., Salin-Pascual, R., Kilduff, T. S., et al. (2001). Hypocretin-2-saporin lesions of the lateral hypothalamus produce narcoleptic-like sleep behavior in the rat. J. Neurosci. 21, 7273-7283. doi: 10.1523/JNEUROSCI.21-18-07273.2001

Gerashchenko, D., Blanco-Centurion, C. A., Miller, J. D., and Shiromani, P. J. (2006). Insomnia following hypocretin2-saporin lesions of the substantia nigra. Neuroscience 137, 29-36. doi: 10.1016/j.neuroscience.2005.08.088

Gjerstad, M. D., Wentzel-Larsen, T., Aarsland, D., and Larsen, J. P. (2007). Insomnia in Parkinson's disease: frequency and progression over time. J. Neurol. Neurosurg. Psychiatry 78, 476-479. doi: 10.1136/jnnp.2006.100370

Gonzalez-Rueda, A., Pedrosa, V., Feord, R. C., Clopath, C., and Paulsen, O. (2018). Activity-dependent downscaling of subthreshold synaptic inputs during slowwave-sleep-like activity in vivo. Neuron 971244-1252, e1245. doi: 10.1016/j. neuron.2018.01.047

Gravotta, L., Gavrila, A. M., Hood, S., and Amir, S. (2011). Global depletion of dopamine using intracerebroventricular 6-hydroxydopamine injection disrupts normal circadian wheel-running patterns and PERIOD2 expression in the rat forebrain. J. Mol. Neurosci. 45, 162-171. doi: 10.1007/s12031-011-9520-8

Halliday, G. M., Li, Y. W., Blumbergs, P. C., Joh, T. H., Cotton, R. G., Howe, P. R., et al. (1990). Neuropathology of immunohistochemically identified brainstem neurons in Parkinson's disease. Ann. Neurol. 27, 373-385. doi: 10.1002/ ana.410270405

Hara, J., Beuckmann, C. T., Nambu, T., Willie, J. T., Chemelli, R. M., Sinton, C. M., et al. (2001). Genetic ablation of orexin neurons in mice results in narcolepsy, hypophagia, and obesity. Neuron 30, 345-354. doi: 10.1016/ s0896-6273(01)00293-8

Hauer, B. E., Pagliardini, S., and Dickson, C. T. (2019). The reuniens nucleus of the thalamus has an essential role in coordinating slow-wave activity between neocortex and hippocampus. eNeuro 6. doi: 10.1523/ENEURO.0365-19.2019 
Hjort, N., Ostergaard, K., and Dupont, E. (2004). Improvement of sleep quality in patients with advanced Parkinson's disease treated with deep brain stimulation of the subthalamic nucleus. Mov. Disord. 19, 196-199. doi: 10.1002/mds.10639

Hsieh, K. C., Robinson, E. L., and Fuller, C. A. (2008). Sleep architecture in unrestrained rhesus monkeys (Macaca mulatta) synchronized to 24-hour lightdark cycles. Sleep 31, 1239-1250. doi: 10.5665/sleep/31.9.1239

Ito, H., Yanase, M., Yamashita, A., Kitabatake, C., Hamada, A., Suhara, Y., et al. (2013). Analysis of sleep disorders under pain using an optogenetic tool: possible involvement of the activation of dorsal raphe nucleus-serotonergic neurons. Mol. Brain 6, 59. doi: 10.1186/1756-6606-6-59

Jackson-Lewis, V., and Przedborski, S. (2007). Protocol for the MPTP mouse model of Parkinson's disease. Nat. Protoc. 2, 141-151. doi: 10.1038/nprot.2006.342

Johannessen, J. N., Chiueh, C. C., Burns, R. S., and Markey, S. P. (1985). Differences in the metabolism of MPTP in the rodent and primate parallel differences in sensitivity to its neurotoxic effects. Life Sci. 36, 219-224. doi: 10.1016/0024-3205(85)90062-1

Jones, B. E. (2003). Arousal systems. Front. Biosci. 8, s438-s451. doi: 10.2741/1074

Kharkar, S., Ellenbogen, J. R., Samuel, M., Rizos, A., Silverdale, M., Chaudhuri, K. R., et al. (2018). Changes in Parkinson's disease sleep symptoms and daytime somnolence after bilateral subthalamic deep brain stimulation in Parkinson's disease. NPJ Parkinsons Dis. 4, 16. doi: 10.1038/s41531-018-0053-5

Kim, S., Kwon, S. H., Kam, T. I., Panicker, N., Karuppagounder, S. S., Lee, S., et al. (2019). Transneuronal propagation of pathologic alpha-synuclein from the gut to the brain models Parkinson's disease. Neuron 103627-641, e627. doi: 10.1016/j.neuron.2019.05.035

Kroeger, D., Ferrari, L. L., Petit, G., Mahoney, C. E., Fuller, P. M., Arrigoni, E., et al. (2017). Cholinergic, glutamatergic, and gabaergic neurons of the pedunculopontine tegmental nucleus have distinct effects on sleep/ wake behavior in mice. J. Neurosci. 37, 1352-1366. doi: 10.1523/ JNEUROSCI.1405-16.2016

Krueger, J. M. (2008). The role of cytokines in sleep regulation. Curr. Pharm. Des. 14, 3408-3416. doi: 10.2174/138161208786549281

Kudo, T., Loh, D. H., Truong, D., Wu, Y., and Colwell, C. S. (2011). Circadian dysfunction in a mouse model of Parkinson's disease. Exp. Neurol. 232, 66-75. doi: 10.1016/j.expneurol.2011.08.003

Kurtis, M. M., Rodriguez-Blazquez, C., Martinez-Martin, P., and Group, E. (2013). Relationship between sleep disorders and other non-motor symptoms in Parkinson's disease. Parkinsonism Relat. Disord. 19, 1152-1155. doi: 10.1016/j. parkreldis.2013.07.026

Laloux, C., Derambure, P., Kreisler, A., Houdayer, E., Brueziere, S., Bordet, R., et al. (2008). MPTP-treated mice: long-lasting loss of nigral TH-ir neurons but not paradoxical sleep alterations. Exp. Brain Res. 186, 635-642. doi: 10.1007/ s00221-008-1268-1

Lang, A. E. (2011). A critical appraisal of the premotor symptoms of Parkinson's disease: potential usefulness in early diagnosis and design of neuroprotective trials. Mov. Disord. 26, 775-783. doi: 10.1002/mds.23609

Lee, S.-H., and Dan, Y. (2012). Neuromodulation of Brain States. Neuron 76, 209222. doi: $10.1016 /$ j.neuron.2012.09.012

Lima, M. M., Andersen, M. L., Reksidler, A. B., Vital, M. A., and Tufik, S. (2007). The role of the substantia nigra pars compacta in regulating sleep patterns in rats. PloS One 2, e513. doi: 10.1371/journal.pone.0000513

Liu, D., and Dan, Y. (2019). A motor theory of sleep-wake control: arousal-action circuit. Annu. Rev. Neurosci. 42, 27-46. doi: 10.1146/ annurev-neuro-080317-061813

Lu, J., Bjorkum, A. A., Xu, M., Gaus, S. E., Shiromani, P. J., and Saper, C. B. (2002). Selective activation of the extended ventrolateral preoptic nucleus during rapid eye movement sleep. J. Neurosci. 22, 4568-4576. doi: 20026455

Lu, J., Sherman, D., Devor, M., and Saper, C. B. (2006). A putative flip-flop switch for control of REM sleep. Nature 441, 589-594. doi: 10.1038/nature04767

Lysen, T. S., Darweesh, S. K. L., Ikram, M. K., Luik, A. I., and Ikram, M. A. (2019). Sleep and risk of parkinsonism and Parkinson's disease: a population-based study. Brain 142 (7), 2013-2022 doi: 10.1093/brain/awz113

Maeda, T., Nagata, K., Kondo, H., and Kanbayashi, T. (2006). Parkinson's disease comorbid with narcolepsy presenting low CSF hypocretin/orexin level. Sleep Med. 7, 662. doi: 10.1016/j.sleep.2006.05.017

Maetzler, W., Liepelt, I., and Berg, D. (2009). Progression of Parkinson's disease in the clinical phase: potential markers. Lancet Neurol. 8, 1158-1171. doi: 10.1016/S1474-4422(09)70291-1
Mao, C. J., Yang, Y. P., Chen, J. P., Wang, F., Chen, J., Zhang, J. R., et al. (2018). Poor nighttime sleep is positively associated with dyskinesia in Parkinson's disease patients. Parkinsonism Relat. Disord. 48, 68-73. doi: 10.1016/j. parkreldis.2017.12.022

Masini, D., Lopes-Aguiar, C., Bonito-Oliva, A., Papadia, D., Andersson, R., Fisahn, A., et al. (2017). The histamine $\mathrm{H} 3$ receptor antagonist thioperamide rescues circadian rhythm and memory function in experimental parkinsonism. Transl. Psychiatry 7, e1088. doi: 10.1038/tp.2017.58

McDowell, K. A., Hadjimarkou, M. M., Viechweg, S., Rose, A. E., Clark, S. M., Yarowsky, P. J., et al. (2010). Sleep alterations in an environmental neurotoxininduced model of parkinsonism. Exp. Neurol. 226, 84-89. doi: 10.1016/j. expneurol.2010.08.005

McDowell, K. A., Shin, D., Roos, K. P., and Chesselet, M. F. (2014). Sleep dysfunction and EEG alterations in mice overexpressing alpha-synuclein. J. Parkinsons Dis. 4, 531-539. doi: 10.3233/JPD-140374

Meredith, G. E., and Rademacher, D. J. (2011). MPTP mouse models of Parkinson's disease: an update. J. Parkinsons Dis. 1, 19-33. doi: 10.3233/JPD-2011-11023

Mery, V. P., Gros, P., Lafontaine, A. L., Robinson, A., Benedetti, A., Kimoff, R. J., et al. (2017). Reduced cognitive function in patients with Parkinson disease and obstructive sleep apnea. Neurology 88, 1120-1128. doi: 10.1212/ WNL.0000000000003738

Monaca, C., Laloux, C., Jacquesson, J. M., Gele, P., Marechal, X., Bordet, R., et al. (2004). Vigilance states in a parkinsonian model, the MPTP mouse. Eur. J. Neurosci. 20, 2474-2478. doi: 10.1111/j.1460-9568.2004.03694.x

Monti, J. M., Ponzoni, A., Jantos, H., Lagos, P., Silveira, R., and Banchero, P. (1999). Effects of accumbens $\mathrm{m}$-chlorophenylbiguanide microinjections on sleep and waking in intact and 6-hydroxydopamine-treated rats. Eur. J. Pharmacol. 364, 89-98. doi: 10.1016/s0014-2999(98)00826-7

Moroni, F., Nobili, L., Iaria, G., Sartori, I., Marzano, C., Tempesta, D., et al. (2014). Hippocampal slow EEG frequencies during NREM sleep are involved in spatial memory consolidation in humans. Hippocampus 24, 1157-1168. doi: 10.1002/ hipo.22299

Moruzzi, G., and Magoun, H. W. (1949). Brain stem reticular formation and activation of the EEG. Electroencephalogr. Clin. Neurophysiol. 1, 455-473. doi: 10.1016/0013-4694(49)90219-9

Neikrug, A. B., Maglione, J. E., Liu, L., Natarajan, L., Avanzino, J. A., CoreyBloom, J., et al. (2013). Effects of sleep disorders on the non-motor symptoms of Parkinson disease. J. Clin. Sleep Med. 9, 1119-1129. doi: $10.5664 / \mathrm{jcsm} .3148$

Oishi, Y., Suzuki, Y., Takahashi, K., Yonezawa, T., Kanda, T., Takata, Y., et al. (2017). Activation of ventral tegmental area dopamine neurons produces wakefulness through dopamine D2-like receptors in mice. Brain Struct. Funct. 222, 29072915. doi: 10.1007/s00429-017-1365-7

Oliveira, L. M., Falquetto, B., Moreira, T. S., and Takakura, A. C. (2018). Orexinergic neurons are involved in the chemosensory control of breathing during the dark phase in a Parkinson's disease model. Exp. Neurol. 309, 107-118. doi: 10.1016/j. expneurol.2018.08.004

Ondo, W. G., Dat Vuong, K., Khan, H., Atassi, F., Kwak, C., and Jankovic, J. (2001). Daytime sleepiness and other sleep disorders in Parkinson's disease. Neurology 57, 1392-1396. doi: 10.1212/wnl.57.8.1392

Ono, D., and Yamanaka, A. (2017). Hypothalamic regulation of the sleep/wake cycle. Neurosci. Res. 118, 74-81. doi: 10.1016/j.neures.2017.03.013

Pagliardini, S., Greer, J. J., Funk, G. D., and Dickson, C. T. (2012). State-dependent modulation of breathing in urethane-anesthetized rats. J. Neurosci. 32, 1125911270. doi: 10.1523/JNEUROSCI.0948-12.2012

Peever, J., and Fuller, P. M. (2017). The Biology of REM Sleep. Curr. Biol. 27, R1237-R1248. doi: 10.1016/j.cub.2017.10.026

Peyron, C., Tighe, D. K., van den Pol, A. N., de Lecea, L., Heller, H. C., Sutcliffe, J. G., et al. (1998). Neurons containing hypocretin (Orexin) project to multiple neuronal systems. J. Neurosci. 18, 9996-10015. doi: 10.1523/ jneurosci.18-23-09996.1998

Porkka-Heiskanen, T., Strecker, R. E., Thakkar, M., Bjorkum, A. A., Greene, R. W., and McCarley, R. W. (1997). Adenosine: a mediator of the sleep-inducing effects of prolonged wakefulness. Science 276, 1265-1268. doi: 10.1126/ science. 276.5316 .1265

Postuma, R. B., Gagnon, J. F., Rompre, S., and Montplaisir, J. Y. (2010). Severity of REM atonia loss in idiopathic REM sleep behavior disorder predicts Parkinson disease. Neurology 74, 239-244. doi: 10.1212/WNL.0b013e3181ca0166 
Qiu, M. H., Yao, Q. L., Vetrivelan, R., Chen, M. C., and Lu, J. (2016). Nigrostriatal Dopamine acting on globus pallidus regulates sleep. Cereb. Cortex 26, 14301439. doi: $10.1093 /$ cercor/bhu241

Reader, T. A., and Gauthier, P. (1984). Catecholamines and serotonin in the rat central nervous system after 6-OHDA, 5-7-DHT and p-CPA. J. Neural Transm. 59, 207-227. doi: 10.1007/bf01250009

Revishchin, A., Moiseenko, L., Kust, N., Bazhenova, N., Teslia, P., Panteleev, D., et al. (2016). Effects of striatal transplantation of cells transfected with GDNF gene without pre- and pro-regions in mouse model of Parkinson's disease. BMC Neurosci. 17, 34. doi: 10.1186/s12868-016-0271-x

Riemann, D., Berger, M., and Voderholzer, U. (2001). Sleep and depression-results from psychobiological studies: an overview. Biol. Psychol. 57, 67-103. doi: 10.1016/s0301-0511(01)00090-4

Saitoh, T., Niijima, K., and Mizuno, Y. (1987). Long-term effect of 1-methyl4-phenyl-1,2,3,6-tetrahydropyridine (MPTP) on striatal dopamine content in young and mature mice. J. Neurol. Sci. 77, 229-235. doi: 10.1016/0022-510x(87)90125-0

Sakata, M., Sei, H., Toida, K., Fujihara, H., Urushihara, R., and Morita, Y. (2002). Mesolimbic dopaminergic system is involved in diurnal blood pressure regulation. Brain Res. 928, 194-201. doi: 10.1016/s0006-8993(01)03402-3

Sakurai, T., Amemiya, A., Ishii, M., Matsuzaki, I., Chemelli, R. M., Tanaka, H., et al. (1998). Orexins and orexin receptors: a family of hypothalamic neuropeptides and g protein-coupled receptors that regulate feeding behavior. Cell 92, 573585. doi: 10.1016/s0092-8674(00)80949-6

Sakurai, T. (2007). The neural circuit of orexin (hypocretin): maintaining sleep and wakefulness. Nat. Rev. Neurosci. 8, 171-181. doi: 10.1038/nrn2092

Santiago, R. M., Barbieiro, J., Lima, M. M., Dombrowski, P. A., Andreatini, R., and Vital, M. A. (2010). Depressive-like behaviors alterations induced by intranigral MPTP, 6-OHDA, LPS and rotenone models of Parkinson's disease are predominantly associated with serotonin and dopamine. Prog. Neuropsychopharmacol. Biol. Psychiatry 34, 1104-1114. doi: 10.1016/j. pnpbp.2010.06.004

Saper, C. B., Chou, T. C., and Scammell, T. E. (2001). The sleep switch: hypothalamic control of sleep and wakefulness. Trends In Neurosci. 24, 726-731. doi: 10.1016/ s0166-2236(00)02002-6

Saper, C. B., Scammell, T. E., and Lu, J. (2005). Hypothalamic regulation of sleep and circadian rhythms. Nature 437, 1257-1263. doi: 10.1038/nature04284

Scammell, T. E., Gerashchenko, D. Y., Mochizuki, T., McCarthy, M. T., Estabrooke, I. V., Sears, C. A., et al. (2001). An adenosine A2a agonist increases sleep and induces Fos in ventrolateral preoptic neurons. Neuroscience 107, 653-663. doi: 10.1016/s0306-4522(01)00383-9

Scammell, T. E., Arrigoni, E., and Lipton, J. O. (2017). Neural circuitry of wakefulness and sleep. Neuron 93, 747-765. doi: 10.1016/j.neuron.2017.01.014

Schenck, C. H., Bundlie, S. R., and Mahowald, M. W. (1996). Delayed emergence of a parkinsonian disorder in $38 \%$ of 29 older men initially diagnosed with idiopathic rapid eye movement sleep behaviour disorder. Neurology 46, 388393. doi: $10.1212 / \mathrm{wnl} .46 .2 .388$

Schenck, C. H., Bundlie, S. R., Ettinger, M. G., and Mahowald, M. W. (2002). Chronic behavioral disorders of human REM sleep: a new category of parasomnia. 1986 [classical article]. Sleep 25, 293-308. doi: 10.1093/sleep/9.2.293

Shan, L., Liu, C. Q., Balesar, R., Hofman, M. A., Bao, A. M., and Swaab, D. F. (2012). Neuronal histamine production remains unaltered in Parkinson's disease despite the accumulation of Lewy bodies and Lewy neurites in the tuberomamillary nucleus. Neurobiol. Aging 33, 1343-1344. doi: 10.1016/j. neurobiolaging.2011.01.004

Shen, W. B., McDowell, K. A., Siebert, A. A., Clark, S. M., Dugger, N. V., Valentino, K. M., et al. (2010). Environmental neurotoxin-induced progressive model of parkinsonism in rats. Ann. Neurol. 68, 70-80. doi: 10.1002/ana.22018

Sherin, J. E., Shiromani, P. J., McCarley, R. W., and Saper, C. B. (1996). Activation of ventrolateral preoptic neurons during sleep. Science 271, 216-219. doi: $10.1126 /$ science.271.5246.216

Simola, N., Morelli, M., and Carta, A. R. (2007). The 6-hydroxydopamine model of Parkinson's disease. Neurotox. Res. 11, 151-167. doi: 10.1007/bf03033565

Strecker, R. E., Morairty, S., Thakkar, M. M., Porkka-Heiskanen, T., Basheer, R., Dauphin, L. J., et al. (2000). Adenosinergic modulation of basal forebrain and preoptic/anterior hypothalamic neuronal activity in the control of behavioral state. Behav. Brain Res. 115, 183-204. doi: 10.1016/s0166-4328(00)00258-8

Suntsova, N., Guzman-Marin, R., Kumar, S., Alam, M. N., Szymusiak, R., and McGinty, D. (2007). The median preoptic nucleus reciprocally modulates activity of arousal-related and sleep-related neurons in the perifornical lateral hypothalamus. J. Neurosci. 27, 1616-1630. doi: 10.1523/jneurosci.3498-06.2007 Surmeier, D. J., Obeso, J. A., and Halliday, G. M. (2017). Selective neuronal vulnerability in Parkinson disease. Nat. Rev. Neurosci. 18, 101-113. doi: 10.1038/nrn.2016.178

Tadaiesky, M. T., Dombrowski, P. A., Figueiredo, C. P., Cargnin-Ferreira, E., Da Cunha, C., and Takahashi, R. N. (2008). Emotional, cognitive and neurochemical alterations in a premotor stage model of Parkinson's disease. Neuroscience 156, 830-840. doi: S0306-4522(08)01247-5 [pii] 10.1016/j.neuroscience.2008.08.035

Taylor, T. N., Caudle, W. M., Shepherd, K. R., Noorian, A., Jackson, C. R., Iuvone, P. M., et al. (2009). Nonmotor symptoms of Parkinson's disease revealed in an animal model with reduced monoamine storage capacity. J. Neurosci. 29, 8103-8113. doi: 10.1523/JNEUROSCI.1495-09.2009

Thannickal, T. C., Lai, Y. Y., and Siegel, J. M. (2007). Hypocretin (orexin) cell loss in Parkinson's disease. Brain 130, 1586-1595. doi: 10.1093/brain/awm097

Thorpy, M. J. (2009). Classification of sleep disorders. Sleep Disorders Medicine: Basic Science, Technical Considerations, and Clinical Aspects. 3rd ed. 275-278. doi: 10.1016/b978-0-7506-7584-0.00020-3

Tieu, K. (2011). A guide to neurotoxic animal models of Parkinson's disease. Cold Spring Harb. Perspect. Med. 1, a009316. doi: 10.1101/cshperspect.a009316

Videnovic, A. (2017). Management of sleep disorders in Parkinson's disease and multiple system atrophy. Mov. Disord. 32, 659-668. doi: 10.1002/mds.26918

Vo, Q., Gilmour, T. P., Venkiteswaran, K., Fang, J., and Subramanian, T. (2014). Polysomnographic features of sleep disturbances and REM sleep behavior disorder in the unilateral 6-OHDA lesioned hemiparkinsonian rat. Parkinsons Dis. 2014, 852965. doi: 10.1155/2014/852965

Yi, P. L., Tsai, C. H., Lu, M. K., Liu, H. J., Chen, Y. C., and Chang, F. C. (2007). Interleukin-1beta mediates sleep alteration in rats with rotenone-induced parkinsonism. Sleep 30, 413-425. doi: 10.1093/sleep/30.4.413

Ylikoski, A., Martikainen, K., Sieminski, M., and Partinen, M. (2015). Parkinson's disease and insomnia. Neurol. Sci. 36, 2003-2010. doi: 10.1007/ s10072-015-2288-9

Yu, X., Zecharia, A., Zhang, Z., Yang, Q., Yustos, R., Jager, P., et al. (2014). Circadian factor BMAL1 in histaminergic neurons regulates sleep architecture. Curr. Biol. 24, 2838-2844. doi: 10.1016/j.cub.2014.10.019

Yuan, H., Sarre, S., Ebinger, G., and Michotte, Y. (2005). Histological, behavioural and neurochemical evaluation of medial forebrain bundle and striatal 6-OHDA lesions as rat models of Parkinson's disease. J. Neurosci. Methods 144, 35-45. doi: 10.1016/j.jneumeth.2004.10.004

Zarow, C., Lyness, S. A., Mortimer, J. A., and Chui, H. C. (2003). neuronal loss is greater in the locus coeruleus than nucleus basalis and substantia nigra in Alzheimer and Parkinson diseases. Arch. Neurol. 60, 337. doi: 10.1001/ archneur.60.3.337

Zhurakovskaya, E., Leikas, J., Pirttimaki, T., Casas Mon, F., Gynther, M., Aliev, R., et al. (2019). Sleep-state dependent alterations in brain functional connectivity under urethane anesthesia in a rat model of early-stage Parkinson's disease. eNeuro 6. doi: 10.1523/ENEURO.0456-18.2019

Zweig, R. M., Jankel, W. R., Hedreen, J. C., Mayeux, R., and Price, D. L. (1989). The pedunculopontine nucleus in Parkinson's disease. Ann. Neurol. 26, 41-46. doi: 10.1002/ana.410260106

Conflict of Interest: The authors declare that the submitted work was carried out in the absence of any personal, professional or financial relationships that could potentially be construed as a conflict of interest.

Copyright (c) 2019 Medeiros, Lopes Aguiar, Moraes and Fisone. This is an openaccess article distributed under the terms of the Creative Commons Attribution License (CC BY). The use, distribution or reproduction in other forums is permitted, provided the original author(s) and the copyright owner(s) are credited and that the original publication in this journal is cited, in accordance with accepted academic practice. No use, distribution or reproduction is permitted which does not comply with these terms. 